\title{
Thermodynamic properties of water sorption of jackfruit (Artocarpus heterophyllus Lam.) as a function of moisture content
}

\author{
Propriedades termodinâmicas de sorção de água da jaca (Artocarpus heterophyllus Lam.) em função \\ do teor de umidade
}

\author{
Ana Paula PRETTE ${ }^{1}$, Francisco de Assis Cardoso ALMEIDA ${ }^{1}$, Harvey Alexander VILLA-VÉLEZ ${ }^{2}$, \\ Javier TELIS-ROMERO ${ }^{2 *}$
}

\begin{abstract}
The Jackfruit tree is one of the most significant trees in tropical home gardens and perhaps the most widespread and useful tree in the important genus Artocarpus. The fruit is susceptible to mechanical and biological damage in the mature state, and some people find the aroma of the fruit objectionable, particularly in confined spaces. The dehydration process could be an alternative for the exploitation of this product, and the relationship between moisture content and water activity provides useful information for its processing and storage. The aim of this study was to determine the thermodynamic properties of the water sorption of jackfruit (Artocarpus heterophyllus Lam.) as a function of moisture content. Desorption isotherms of the different parts of the jackfruit (pulp, peduncle, mesocarp, peel, and seed) were determined at four different temperatures $(313.15,323.15,333.15$, and $343.15 \mathrm{~K})$ in a water activity range of $0.02-0.753$ using the static gravimetric method. Theoretical and empirical models were used to model the desorption isotherms. An analytical solution of the Clausius-Clapeyron equation was proposed to calculate the isosteric heat of sorption, the differential entropy, and Gibbs' free energy using the Guggenhein-Anderson-de Boer and Oswin models considering the effect of temperature on the hygroscopic equilibrium.

Keywords: desorption isotherms; thermodynamical properties; jackfruit.
\end{abstract}

\section{Resumo}

A jaqueira é uma das árvores mais significativas nos quintais tropicais e, talvez, a árvore mais importante e útil do gênero Artocarpus. O fruto é suscetível a danos mecânicos e biológicos no estado maduro, e seu aroma é desagradável para algumas pessoas, quando em espaços fechados. O processo de desidratação pode ser uma alternativa para a exploração deste produto, e a relação entre a umidade e a atividade de água fornece informações úteis para seu processamento e armazenamento. O objetivo do trabalho foi determinar as propriedades termodinâmicas de sorção da água em frutos de jaca (Artocarpus heterophyllus Lam.), em função do conteúdo de umidade. Para isto, foram determinadas as isotermas de dessorção das diferentes partes da jaca (polpa, pedúnculo, mesocarpo, cascas e sementes) em quatro temperaturas (313.15, $323.15,333.15$ e $343.15 \mathrm{~K}$ ) na faixa de atividade de água de 0,020-0,753, através do método gravimétrico estático. Modelos teóricos e empíricos foram usados para modelar as isotermas de dessorção. A solução analítica da equação de Clausius-Clapeyron foi empregada para calcular o calor isostérico de sorção, a entropia diferencial e a energia livre de Gibbs’ através dos modelos de Guggenhein-Anderson-de Boer e Oswin, considerando o efeito da temperatura sob o equilíbrio higroscópico.

Palavras-chave: isotermas de sorção; propriedades termodinâmicas; jaca.

\section{Introduction}

The jackfruit (Artocarpus heterophyllus Lam.) originated in the rain forests of the Western Ghats of India and quickly spread to other parts of India, Southeast Asia, the East Indies, and ultimately the Philippines. It is frequently planted in Central and Eastern Africa and is fairly popular in Brazil and Surinam. Jackfruit is the largest tree-borne fruit in the world, reaching 36.28 kilograms in weight and up to 91.44 centimeters long and 50.8 centimeters in diameter. The outside of the compound fruit is green or yellow when ripe, and the inside consists of large edible bulbs of yellow, banana-flavored flesh that enclose a smooth, oval, light-brown seed. The seed is 1.90 to $3.81 \mathrm{~cm}$ long and 1.27 to $1.90 \mathrm{~cm}$ thick, and is white and crisp within. There may be from 100 to up to 500 seeds in a single fruit, which are viable for no more than three or four days. When fully ripe, the unopened jackfruit emits a strong disagreeable odor, while the pulp of the opened fruit smells of pineapple and banana. The fruit is rich in components such as fibers, phosphorous, calcium, potassium, magnesium, and vitamin C (CAMPBELL; EL-SAWA, 1998; CHANDRIKA; JANSZ; WARNASURIYA, 2005). It is little consumed in Brazil due to a limited spread throughout the country, and its harvest is restricted to a local production in the northeast of Brazil (HAQ, 2006).

\section{Received 21/8/2012}

Accepted 5/1/2013 (005802)

${ }^{1}$ Departamento de Engenharia Agrícola, Centro de Tecnologia e Recursos Naturais, Universidade Federal de Campina Grande - UFCG, CEP 58429-900, Campina Grande, PB, Brasil

2 Departamento de Engenharia e Tecnologia de Alimentos, Universidade Estadual Paulista - UNESP, CP 136, CEP 15054-000, São José do Rio Preto, SP, Brasil, e-mail: javier@ibilce.unesp.br

${ }^{*}$ Corresponding author 
Currently the jackfruit has few prospects for sustainable economic recovery in research areas such as genetic improvement, management of commercial plantations, which are basically nonexistent and phytosanitary control, apart from the use of residues and their compounds. The edible fruit, characterized by the pulp, is consumed almost entirely in nature and is high perishable, leading to high post-harvest losses. This fact highlights the need for simple and inexpensive processes that could provide ways of using the fruit. One option is dehydration, reducing the moisture and hence limiting microbial development and preventing biochemical reactions, avoiding the usual rapid deterioration of the fresh fruit (CHEN; HEN, 1975). The jackfruit has a significant amount of sub-products such as the peel, mesocarp, and seeds, which are available as a residue for the candy, raisin, and the bakery industries. The seeds are used as food in a rudimentary form and can be boiled or roasted. They are nutritious, tasty, and suitable for intestinal disorders (CAMPBELL; EL-SAWA, 1998). The peel (epicarp + mesocarp) and the central axis of the inflorescence (peduncle) are basically discarded or used in animal feed. Due to its organoleptic qualities, the jackfruit and its residues could represent a potential socioeconomic source and food for exploitation, constituting an alternative to increase family income as well as offering the options of investing in the processing of candy, raisins, juices, jams and liqueurs amongst others, to small and micro companies (ASQUIERI; RABÊLO; SILVA, 2008; KHYRUNNISA et al., 1989).

Knowing the final moisture content provides information that can be used to estimate the energy requirements for processing and also the optimal conditions for storage, mixing, and drying (EIM et al., 2011). The thermodynamic properties may also help establish the final moisture content and estimate the energy requirements for processing. Properties such as the enthalpy, entropy, and Gibb's free energy are essential to represent and describe the reactions and phenomena that occur at the intermolecular level in materials. These properties represent the amount of energy, the order or excited state, and the chemical equilibrium, respectively, of water molecules inside the material (BROVCHENKO; OLEINIKOVA, 2008). Changes in some of the thermodynamic properties with respect to moisture content and temperature can provide a good description of the moisture sorption mechanisms and can be used to estimate transitional points between them (GONELLI et al., 2010; SIMAL et al., 2007). In view of the importance of understanding the hygroscopicity of agricultural products, this study aimed to determine the thermodynamic properties of water sorption of jackfruit pulp, peduncle, mesocarp, peel, and seeds using the sorption isotherms obtained under several conditions of temperature and water activity.

\section{Materials and methods}

\subsection{Raw material}

The jackfruit (Artocarpus heterophyllus Lam.) was acquired from a central fruit distribution center "CEASA", in the city of São José do Rio Preto, São Paulo State, Brazil. The entire fruit was taken to the laboratory of the Engineering and Food Technology Department, UNESP, and kept under refrigeration $(290.15 \mathrm{~K})$ for future experiments.

\subsection{Sample preparation}

The entire fruit was washed with distilled water to remove foreign matter. After cleaning, the fruit was cut up and the constituents separated. The peduncle (central axis) was removed manually from the fruit, exposing the mesocarp and pulp. The pulp was then separated from the mesocarp and the seeds immediately removed. The mesocarp was separated from the peel with the aid of a stainless steel knife. The particle size of all the jackfruit items (pulp, peduncle, mesocarp, peel and seed) was reduced using a food processor (model RI 17625/71, Philips, Japan) to obtain $500 \mathrm{~g}$ of each sample, used for the subsequent testing.

\subsection{Sorption isotherms}

The equilibrium moisture contents of the different parts of the jackfruit were determined using the static gravimetric method (JOWITT et al., 1987) at temperatures of 313.15, 323.15, 333.15 , and $343.15 \mathrm{~K}$. The experimental setup consisted of eight glass jars of $10 \mathrm{~cm}$ of diameter and $13 \mathrm{~cm}$ of height with hermetic cover, containing different saturated salt solutions, corresponding to values for water activity $\left(a_{w}\right)$ from 0.020 to 0.753 . Each jar was filled to a depth of $1.5 \mathrm{~cm}$ with the appropriate salt solution. Triplicate samples of around $1 \mathrm{~g}$ of the different parts of jackfruit were weighed into small plastic receptacles and placed on tripods to avoid contact with the salt solution inside the jar. The jars were subsequently placed in a temperature-controlled chamber (BOD, Model TE-391, TECNAL, Brazil) under different temperature and relative humidity conditions, according to the salt used in the jar. The sample weights were controlled until the moisture content on a dry weight basis did not exceed $0.1 \%$ (time elapsed - from 4 to 5 weeks), at which equilibrium was assumed, thus assuring that the equilibrium moisture content of each sample corresponded to the water activity. The initial moisture content of the jackfruit pulp, peduncle, mesocarp, peel, and seed was determined according to the AOAC method 926.12 (ASSOCIATION..., 1997) to determine the equilibrium moisture content from the weight registered up to equilibrium. The values obtained for the equilibrium moisture contents, water activities, and temperatures were used to construct the desorption isotherms for the different parts of jackfruit.

\subsection{Modeling of sorption isotherms}

The sorption isotherms of the jackfruit pulp, peduncle, mesocarp, peel, and seed were simulated using the theoretical model of Guggenhein-Anderson-de Boer "GAB” (Equation 1) and the empirical models of Henderson (Equation 2), Oswin (Equation 3), Halsey (Equation 4), and Iglesias-Chirife (Equation 5). In the models, the moisture content was described as a function of both temperature and water activity (ANDERSON, 1946; CHEN; MOREY, 1989; IGLESIAS; CHIRIFE, 1976). 


$$
\begin{aligned}
& X=\frac{X_{m} C_{G} K_{G} a_{w}}{\left(1-K_{G} a_{w}\right)\left(1+\left(C_{G}-1\right) K_{G} a_{w}\right)} \\
& X=\left[\frac{\ln \left(1-a_{w}\right)}{-A(B+T)}\right]^{\frac{1}{C}} \\
& X=(A+B T)\left[\frac{a_{w}}{\left(1-a_{w}\right)}\right]^{\frac{1}{C}} \\
& X=\left[\frac{\exp (A-B T)}{-\ln \left(a_{w}\right)}\right]^{\frac{1}{C}} \\
& X=(A+B T)\left[\frac{a_{w}}{\left(1-a_{w}\right)}\right]+C
\end{aligned}
$$

where $A, B, C$ are the constants of the empirical models; $a_{w}$ is the water activity; and $X$ is the equilibrium moisture content $\left(\mathrm{kg} \cdot \mathrm{kg}^{-1}, \mathrm{~d} . b.\right)$. For the theoretical model of GAB $X_{m}$ represent the average equilibrium moisture of the monolayer $\left(\mathrm{kg} \cdot \mathrm{kg}^{-1}\right.$, d.b.) and, the constants $C_{G}$ and $K_{G}$ can be written according to Equations 6 and 7, respectively:

$$
\begin{gathered}
C_{G}=C_{0} \exp \left(\frac{H_{m}-H_{n}}{R T}\right) \\
K_{G}=K_{0} \exp \left(\frac{\lambda-H_{n}}{R T}\right)
\end{gathered}
$$

where $C_{0}$ and $K_{0}$ are the GAB model parameters, $H_{m}$ and $H_{n}$ are the water sorption heats of the monolayer and multilayer $\left(\mathrm{kJ} \cdot \mathrm{mol}^{-1}\right)$, respectively, $\lambda$ is the vaporization energy of pure water $\left(\mathrm{kJ} \cdot \mathrm{mol}^{-1}\right), T$ is the absolute temperature $(\mathrm{K})$, and $R$ is the ideal gas constant $\left(8.314 \mathrm{~kJ} \cdot \mathrm{K}^{-1} \cdot \mathrm{kmol}^{-1}\right)($ TIMMERMANN; CHIRIFE; IGLESIAS, 2001).

\subsection{Thermodynamic properties of water sorption}

The enthalpy of sorption was calculated using the ClausiusClayperon equation (Equation 8), and the procedures of the American Society of Agricultural Engineers "ASAE Standards" (AMERICAN..., 1998) were used to estimate the heat of vaporization of pure water $(\lambda)$ in relation to the temperature:

$Q_{s t}=\lambda-R \frac{\partial\left(\ln a_{w}\right)}{\partial(1 / T)}=\lambda+\frac{R T^{2}}{a_{w}} \frac{\partial a_{w}}{\partial T}$

Therefore, the best fitted model for the sorption isotherms was used to determine the analytical partial derivative of the water activity with respect to temperature, according to Equation 8. The calculation of $Q_{s t}$ corresponded to the maximum and minimum temperatures used in the study. This method is the so called "direct method", which avoids the linearization applied between $\ln a_{w}$ vs.1/T in the thermodynamic statistical method used in products such as: safflower petals and tarragon (KAYA; KAHYAOGLU, 2007), grape skin (KAYA;
KAHYAOGLU, 2005), walnut kernels (TOGRUL; ARSLAN, 2007), and corn (CHAYJAN et al., 2010), resulting in the calculation of $Q_{s}$ under several moisture contents.

The differential entropy $(\Delta S)\left(\mathrm{kJ} \cdot \mathrm{mol}^{-1} \cdot \mathrm{K}^{-1}\right)$ was obtained directly from Equation 9 at the temperatures of 313.15 and 343.15 K (HILL; EMMETT; JOYNER, 1951).

$\ln a_{w}=-\frac{\left(Q_{s t}-\lambda\right)}{R T}-\frac{\Delta S}{R}$

The same procedure was carried out for Gibbs' free energy $(\Delta G)\left(\mathrm{kJ} \cdot \mathrm{mol}^{-1}\right)$ using Equation 10:

$\Delta G=R T \ln a_{w}$

According to Mulet et al. (2002) and García-Pérez et al. (2008), $\Delta G$ is known as the thermodynamic potential and measures the "useful" or process-initiating work obtained from an isothermal isobaric thermodynamic system. As in mechanics, where the potential energy is defined as the capacity to do work, different potentials have different meanings. Changes in the $\Delta G$ values provide a criterion to evaluate if water sorption is a spontaneous $(\Delta G<0)$ or non-spontaneous process $(\Delta G>0)$ (KRUG; HUNTER; GRIEGER, 1976a, b).

\subsection{Estimation of the parameters and statistical analysis}

The parameters of the theoretical and empirical models (Equations 1-7) were estimated by fitting the equations to the experimental data using the "nlinfit" function of the Statistic Toolbox of Matlab ${ }^{\star} 7.1$ (The MathWorks Inc., Natick, MA, USA) and considering the "robust" fitting option. This function uses the Gauss-Newton algorithm with Levenberg-Marquardt modifications to interactively reweigh the response values and re-compute a least-square fit of a non-linear model. The $95 \%$ confidence intervals of the estimated model parameters were determined using the "nlparci" function of the same Matlab Toolbox.

The adjusted $R^{2}\left(\mathrm{R}_{a d j}^{2}\right)$ (Equation 11) and mean relative error $(M R E, \%)$ (Equation 12) were used to assess the model accuracy. The statistical parameter $\mathrm{R}_{\text {adj }}^{2}$ is an indicative of adjusts of the number of explanatory terms in a model and penalizes the adding of independent variable(s) that do not belong in the model. On the other hand, $M R E(\%)$ is a measure of the standard error in the estimation (SHESKIN, 2004).

$R_{a d j}^{2}=1-\left[\left(\frac{n-1}{n-p-1}\right)\left(1-R^{2}\right)\right]$

$M R E=\frac{100}{N} \sum_{k=1}^{N} \frac{\left|y_{k}-y_{k}^{*}\right|}{y_{k}^{*}}$

In Equations 11 and 12, $n$ is the number of observations; $P$ is the number of parameters; $y$ represents the experimental values; $y^{*}$ represents the estimated values; $\bar{y}$ is the average of the experimental values, $k$ is the product vector between 
experimental and estimated values, and $N$ is the number of experimental values.

\section{Results and discussion}

\subsection{Experimental desorption isotherms}

Table 1 shows the experimental results obtained for the desorption isotherms of the jackfruit items, with the corresponding standard deviations. The equilibrium moisture contents ranged from: 0.001 to $0.278 \mathrm{~kg} \cdot \mathrm{kg}^{-1} \mathrm{~d}$.b. for the pulp, 0.043 to $0.229 \mathrm{~kg} \cdot \mathrm{kg}^{-1} \mathrm{~d}$.b. for the peduncle, 0.001 to $0.231 \mathrm{~kg} \cdot \mathrm{kg}^{-1}$ d.b. for the mesocarp, 0.001 to $0.203 \mathrm{~kg} \cdot \mathrm{kg}^{-1} \mathrm{~d}$.b. for the peel, and 0.010 to $0.100 \mathrm{~kg} \cdot \mathrm{kg}^{-1} \mathrm{~d}$.b. for the seed, whereas the water activities were all between 0.020 and 0.753 . A similar tendency was observed for all of the experimental results obtained for the pulp and mesocarp items. This can be explained by the fact that these items presented similar chemical compositions, and they were differentiated one from the other because the pulp is the result of the fusion of fibers from the mesocarp, hydrolyzed during ripening. In addition, the equilibrium moisture content values decreased as the temperature increased, at each water activity level. These items are mainly composed of cellulose, hemicellulose, and pectin, and at low temperatures, when the system saturation pressure is lower, they may be able to absorb water (BARBOSA-CÁNOVAS et al., 2007; QUIÉVY et al., 2010).

In order to explain the strong relationship between temperature and water activity, some studies have indicated that the decrease in moisture content is due to an increase in the excited state of the water molecules at high temperatures, increasing the distances between the molecules and reducing their attractive forces. Other studies have suggested that the increase in temperature causes incorporation of water, which reduces the number of active sites and promotes physical or chemical changes in the different materials of jackfruit (AL-MUHTASEB; McMINN; MAGEE, 2002; SAMAPUNDO et al., 2007).

Table 1. Experimental equilibrium moisture contents for the different parts of jackfruit ${ }^{\star}$ at temperatures ranging from 313.15 to $343.15 \mathrm{~K}$.

\begin{tabular}{|c|c|c|c|c|c|c|}
\hline \multirow{2}{*}{$T(\mathrm{~K})$} & \multirow{2}{*}{$\left(a_{w}\right)$} & \multicolumn{5}{|c|}{$(X)$} \\
\hline & & Pulp & Peduncle & Mesocarp & Peel & Seed \\
\hline \multirow[t]{8}{*}{313.15} & 0.066 & $0.008 \pm 0.000$ & $0.052 \pm 0.001$ & $0.006 \pm 0.000$ & $0.003 \pm 0.000$ & $0.019 \pm 0.000$ \\
\hline & 0.111 & $0.013 \pm 0.000$ & $0.067 \pm 0.002$ & $0.010 \pm 0.000$ & $0.006 \pm 0.000$ & $0.026 \pm 0.000$ \\
\hline & 0.206 & $0.027 \pm 0.001$ & $0.097 \pm 0.002$ & $0.022 \pm 0.001$ & $0.013 \pm 0.000$ & $0.037 \pm 0.001$ \\
\hline & 0.319 & $0.048 \pm 0.001$ & $0.113 \pm 0.002$ & $0.038 \pm 0.002$ & $0.024 \pm 0.001$ & $0.048 \pm 0.001$ \\
\hline & 0.432 & $0.076 \pm 0.001$ & $0.135 \pm 0.002$ & $0.061 \pm 0.001$ & $0.039 \pm 0.000$ & $0.059 \pm 0.001$ \\
\hline & 0.506 & $0.101 \pm 0.004$ & $0.158 \pm 0.005$ & $0.081 \pm 0.004$ & $0.051 \pm 0.002$ & $0.069 \pm 0.002$ \\
\hline & 0.615 & $0.154 \pm 0.001$ & $0.190 \pm 0.005$ & $0.122 \pm 0.001$ & $0.092 \pm 0.000$ & $0.079 \pm 0.002$ \\
\hline & 0.753 & $0.278 \pm 0.005$ & $0.229 \pm 0.003$ & $0.223 \pm 0.005$ & $0.203 \pm 0.003$ & $0.100 \pm 0.002$ \\
\hline \multirow[t]{8}{*}{323.15} & 0.059 & $0.005 \pm 0.000$ & $0.049 \pm 0.000$ & $0.005 \pm 0.000$ & $0.003 \pm 0.000$ & $0.022 \pm 0.000$ \\
\hline & 0.110 & $0.011 \pm 0.000$ & $0.064 \pm 0.001$ & $0.009 \pm 0.000$ & $0.005 \pm 0.000$ & $0.028 \pm 0.000$ \\
\hline & 0.189 & $0.021 \pm 0.000$ & $0.088 \pm 0.002$ & $0.019 \pm 0.000$ & $0.009 \pm 0.000$ & $0.038 \pm 0.000$ \\
\hline & 0.314 & $0.041 \pm 0.000$ & $0.105 \pm 0.001$ & $0.036 \pm 0.000$ & $0.017 \pm 0.000$ & $0.047 \pm 0.001$ \\
\hline & 0.432 & $0.068 \pm 0.000$ & $0.127 \pm 0.002$ & $0.060 \pm 0.000$ & $0.031 \pm 0.000$ & $0.056 \pm 0.001$ \\
\hline & 0.489 & $0.086 \pm 0.002$ & $0.145 \pm 0.004$ & $0.075 \pm 0.001$ & $0.040 \pm 0.000$ & $0.059 \pm 0.001$ \\
\hline & 0.599 & $0.134 \pm 0.002$ & $0.174 \pm 0.003$ & $0.121 \pm 0.001$ & $0.066 \pm 0.000$ & $0.071 \pm 0.001$ \\
\hline & 0.746 & $0.260 \pm 0.002$ & $0.221 \pm 0.002$ & $0.231 \pm 0.002$ & $0.151 \pm 0.001$ & $0.084 \pm 0.001$ \\
\hline \multirow[t]{8}{*}{333.15} & 0.045 & $0.003 \pm 0.000$ & $0.046 \pm 0.001$ & $0.003 \pm 0.000$ & $0.001 \pm 0.000$ & $0.014 \pm 0.000$ \\
\hline & 0.110 & $0.009 \pm 0.000$ & $0.060 \pm 0.000$ & $0.008 \pm 0.000$ & $0.004 \pm 0.000$ & $0.022 \pm 0.000$ \\
\hline & 0.175 & $0.015 \pm 0.000$ & $0.082 \pm 0.001$ & $0.014 \pm 0.000$ & $0.008 \pm 0.000$ & $0.027 \pm 0.000$ \\
\hline & 0.307 & $0.033 \pm 0.001$ & $0.099 \pm 0.003$ & $0.030 \pm 0.000$ & $0.016 \pm 0.000$ & $0.036 \pm 0.001$ \\
\hline & 0.432 & $0.059 \pm 0.000$ & $0.119 \pm 0.000$ & $0.053 \pm 0.000$ & $0.028 \pm 0.000$ & $0.043 \pm 0.000$ \\
\hline & 0.473 & $0.071 \pm 0.001$ & $0.132 \pm 0.001$ & $0.062 \pm 0.001$ & $0.033 \pm 0.000$ & $0.046 \pm 0.000$ \\
\hline & 0.590 & $0.117 \pm 0.002$ & $0.163 \pm 0.001$ & $0.106 \pm 0.001$ & $0.055 \pm 0.001$ & $0.052 \pm 0.000$ \\
\hline & 0.740 & $0.237 \pm 0.001$ & $0.206 \pm 0.001$ & $0.210 \pm 0.002$ & $0.132 \pm 0.001$ & $0.065 \pm 0.000$ \\
\hline \multirow[t]{8}{*}{343.15} & 0.020 & $0.001 \pm 0.000$ & $0.043 \pm 0.000$ & $0.001 \pm 0.000$ & $0.001 \pm 0.000$ & $0.010 \pm 0.000$ \\
\hline & 0.110 & $0.007 \pm 0.000$ & $0.058 \pm 0.000$ & $0.006 \pm 0.000$ & $0.003 \pm 0.000$ & $0.019 \pm 0.000$ \\
\hline & 0.162 & $0.012 \pm 0.000$ & $0.075 \pm 0.002$ & $0.010 \pm 0.000$ & $0.006 \pm 0.000$ & $0.022 \pm 0.001$ \\
\hline & 0.294 & $0.026 \pm 0.000$ & $0.093 \pm 0.000$ & $0.023 \pm 0.001$ & $0.012 \pm 0.000$ & $0.030 \pm 0.000$ \\
\hline & 0.432 & $0.051 \pm 0.000$ & $0.112 \pm 0.000$ & $0.046 \pm 0.000$ & $0.023 \pm 0.000$ & $0.039 \pm 0.001$ \\
\hline & 0.458 & $0.058 \pm 0.001$ & $0.121 \pm 0.002$ & $0.052 \pm 0.000$ & $0.025 \pm 0.000$ & $0.042 \pm 0.001$ \\
\hline & 0.587 & $0.104 \pm 0.000$ & $0.146 \pm 0.001$ & $0.094 \pm 0.000$ & $0.049 \pm 0.000$ & $0.047 \pm 0.001$ \\
\hline & 0.739 & $0.220 \pm 0.001$ & $0.191 \pm 0.001$ & $0.198 \pm 0.000$ & $0.106 \pm 0.001$ & $0.058 \pm 0.001$ \\
\hline
\end{tabular}

${ }^{\star}$ Mean and standard deviation for three replicates. $T$ : temperature (K); X: equilibrium moisture content $\left(\mathrm{kg}^{\circ} \mathrm{kg}^{-1} \mathrm{~d} \cdot \mathrm{b}\right.$.); $a_{w}$ : water activity (dimensionless). 
The results of equilibrium moisture content reported in the literature for products such as persimmon skin (TELIS et al., 2000), pectin (TSAMI; KROKIDA; DROUZAS, 1998), Tunisian olive leaves (BAHLOUL; BOUDHRIOUA; KECHAOU, 2008), tomato pulp (GUOLA et al., 2008), and sesame seeds (AVIARA; AJIBOLA; DAIRO, 2002) showed similarities between the experimental values and the sorption isotherms obtained for the peel, peduncle, mesocarp, pulp, and seed, respectively.

\subsection{Modeling the desorption isotherms}

The desorption isotherms of the jackfruit items were modeled using the theoretical model of GAB and the empirical models of Oswin, Henderson, Iglesias \& Chirife and Halsey. In the present study, the best model to fit the isotherms of each jackfruit item was shown. For the jackfruit items (pulp, mesocarp and peel), the GAB model showed the best results and statistical validations (Table 2), the statistical results providing $\mathrm{R}_{a d j}^{2}$ and MRE of 0.999 and $2.129 \%$ for the pulp, 0.998 and $3.439 \%$ for the mesocarp, and 0.998 and $7.592 \%$ for the peel, indicating satisfactory agreement between the experimental and calculated values using the GAB model. Table 2 also shows the confidence intervals.

The average equilibrium moisture of the monolayer for the pulp, mesocarp and peel items (calculated at temperatures between 313.15 and $343.15 \mathrm{~K}$ ) showed values of 0.101 , $8.204 \times 10^{-2}$ and $3.523 \times 10^{-2} \mathrm{~kg} \cdot \mathrm{kg}^{-1}$, d.b., respectively. In addition, the values obtained for the GAB parameter $C$ decreased as the temperature increased, whereas the values for the GAB parameter $K$ increased as the temperature increased. For all jackfruit items, the values for constant $K$ were below one, indicating that there was a difference in free enthalpy between the sorbate molecules in the pure liquid and those in the second sorption stage in the layer above the monolayer (RIZVI, 2005).

The heat sorption values for the monolayers $\left(H_{m}\right)$ were $76.18,73.70$ and $70.90 \mathrm{~kJ} \cdot \mathrm{mol}^{-1}$ for the pulp, mesocarp, and peel, respectively, (using values of $\lambda$ between 44.2 and $42.0 \mathrm{~kJ} \cdot \mathrm{mol}^{-1}$ corresponding to the temperature range of 313.15-343.15 K). Values to the same order were obtained by authors in products such as pineapple $97.0 \mathrm{~kJ} \cdot \mathrm{mol}^{-1}$ (SIMAL et al., 2007), morel $50.6 \mathrm{~kJ} \cdot \mathrm{mol}^{-1}$ (MULET et al., 2002), lemon peel $43.0 \mathrm{~kJ} \cdot \mathrm{mol}^{-1}$ (GARCÍA-PÉREZ et al., 2008), and overripe banana 96.68, 97.82 and $74.42 \mathrm{~kJ} \cdot \mathrm{mol}^{-1}$ for the peel, pedicel, and pulp, respectively (VILLA-VÉLEZ et al., 2012). The values obtained for the heat sorption of the multilayers $\left(H_{n}\right)$ were 57.31, 57.98 and $54.66 \mathrm{~kJ} \cdot \mathrm{mol}^{-1}$ for the pulp, mesocarp, and peel, respectively. These values were very close and consistent with the theory suggesting that the states of the sorbate molecules in the second and higher layers were equal, but different from those in the liquid-like state (BARBOSA-CÁNOVAS et al., 2007; RIZVI, 2005).

For the seed and peduncle of the jackfruit, the Oswin model presented the best fitted isotherms, with statistical values of $\mathrm{R}^{2}{ }_{a d j}=0.981$ and $\operatorname{MRE}(\%)=5.914$, and $\mathrm{R}^{2}{ }_{a d j}=0.993$ and $\operatorname{MRE}(\%)=3.933$, respectively. Table 3 shows the estimated parameters with the corresponding statistical validation for the Oswin model.

Table 2. Estimated GAB model parameters and statistical results.

\begin{tabular}{|c|c|c|c|c|c|c|c|}
\hline \multirow{2}{*}{ Item } & \multicolumn{5}{|c|}{ Parameters with $95 \%$ confidence intervals } & \multirow{2}{*}{$\mathrm{R}_{a d j}^{2}$} & \multirow{2}{*}{$\operatorname{MRE}(\%$} \\
\hline & $X_{m}$ & $C_{0}$ & $K_{0}$ & $H_{m}$ & $H_{n}$ & & \\
\hline Pulp & 0.103 & $5.771 \times 10^{-4}$ & 226.25 & 77.13 & 57.54 & 0.999 & 1.922 \\
\hline$L I$ & 0.093 & $3.228 \times 10^{-4}$ & 211.69 & 75.78 & 57.33 & & \\
\hline$L S$ & 0.113 & $8.313 \times 10^{-4}$ & 240.80 & 78.49 & 57.74 & & \\
\hline Mesocarp & $8.513 \times 10^{-2}$ & $2.696 \times 10^{-3}$ & 264.14 & 73.50 & 57.95 & 0.998 & 3.439 \\
\hline$L I$ & $-8.861 \times 10^{-2}$ & $-2.154 \times 10^{-2}$ & -58.251 & 45.98 & 54.07 & & \\
\hline$L S$ & $2.589 \times 10^{-1}$ & $2.693 \times 10^{-2}$ & 586.53 & 101.01 & 61.83 & & \\
\hline Peel & $3.523 \times 10^{-2}$ & $2.393 \times 10^{-3}$ & 87.624 & 70.90 & 54.66 & 0.998 & 7.592 \\
\hline$L I$ & $2.722 \times 10^{-2}$ & $-3.701 \times 10^{-3}$ & 73.180 & 63.14 & 54.27 & & \\
\hline$L S$ & $4.334 \times 10^{-2}$ & $8.488 \times 10^{-3}$ & 102.070 & 78.66 & 55.06 & & \\
\hline
\end{tabular}

$X_{m}$ :average equilibrium moisture of the monolayer $\left(\mathrm{kg} \cdot \mathrm{kg}^{-1}, \mathrm{~d} . \mathrm{b}.\right) ; C_{0}$ and $K_{0}$ : GAB model parameters (dimensionless); $H_{m}$ : sorption heat of the monolayer $\left(\mathrm{kJ} \cdot \mathrm{mol}^{-1}\right) ; H_{n}$ : sorption heat of the multilayer $\left(\mathrm{kJ} \cdot \mathrm{mol}^{-1}\right)$; LI: lower limit; LS: upper limit.

Table 3. Estimated Oswin parameters and statistical results.

\begin{tabular}{|c|c|c|c|c|c|}
\hline \multirow{2}{*}{ Item } & \multicolumn{3}{|c|}{ Parameters with 95\% confidence intervals } & \multirow{2}{*}{$\mathrm{R}_{a d j}^{2}$} & \multirow{2}{*}{$\operatorname{MRE}(\%)$} \\
\hline & $A$ & $B$ & $C$ & & \\
\hline Seed & 0.334 & $-8.559 \times 10^{-4}$ & 2.727 & 0.981 & 5.914 \\
\hline$L L$ & 0.298 & $-9.651 \times 10^{-4}$ & 2.549 & & \\
\hline$U L$ & 0.370 & $-7.468 \times 10^{-4}$ & 2.905 & & \\
\hline Peduncle & 0.411 & $-8.220 \times 10^{-4}$ & 2.624 & 0.993 & 3.933 \\
\hline$L L$ & 0.356 & $-9.895 \times 10^{-4}$ & 2.526 & & \\
\hline$U L$ & 0.466 & $-6.545 \times 10^{-4}$ & 2.723 & & \\
\hline
\end{tabular}

$A$ (dimensionless), $B\left(\mathrm{~K}^{-1}\right)$ and $C$ (dimensionless): Oswin empirical parameters; $L L$ : lower limit; $U L$ : upper limit. 
Oswin's equation has been widely applied to foodstuffs such as seeds and grains, but when compared to the GAB model and other empirical models, its applicability was found to be less versatile (TIMMERMANN; CHIRIFE; IGLESIAS, 2001). In terms of specificity, the Oswin model is advantageous due to its suitability to represent the entire sorption isotherm at different temperatures and low moisture contents and water activity. In this study, the values of the empirical parameters of the Oswin model were calculated as a function of the temperature. These values showed the same order, demonstrating that both items had similar compositions. Furthermore, due to the goodness of fit of the model, very close values were observed between the simulated and experimental data for moisture content. Therefore, this model has been recommended for estimating the equilibrium moisture content of the seed and peduncle of the jackfruit. Some studies on the sorption isotherms of products such as rice grain (DA-WEN, 1999), yellow dent corn (SIMBARASHE et al., 2007), pea seeds (CHEN, 2003), broad been seeds (MENKOV, 2000), and pearl millet grain (GONELLI et al., 2010), suggested that the Oswin model is one of the most appropriate models to describe the hygroscopicity phenomenon of foodstuffs with low moisture contents.

Figure 1 shows exponential curves, characteristic of products with high moisture content and sugar (jackfruit pulp, mesocarp and peel), and closed sigmoidal curves, characteristic of products with low water content (seed and peduncle) (BRUNAUER et al., 1940; BRUNAUER; EMMETT; TELLER, 1938).

\subsection{Thermodynamic properties of water sorption}

The Clausius-Clapeyron equation (Equation 8) was used to calculate the isosteric heat of sorption $\left(Q_{s t}, \mathrm{~kJ} \cdot \mathrm{mol}^{-1}\right)$ for the different parts of jackfruit from the water activity (Equations 13 and 14) from the GAB and Oswin model parameters and the posterior derivation of the water activity with respect to temperature (Equations 15 and 16), respectively.

$$
\begin{aligned}
& \alpha=(C-1) K^{2} ; \beta=\left[2-C\left(1-X_{m} / X\right)\right] K \\
& a_{w}=\left[\left(\frac{A+B T}{X}\right)^{(C)}+1\right]^{-1} \\
& \frac{\partial a_{w}}{\partial T}=\frac{\left(\beta a_{w}-1\right) \frac{d \alpha}{d T}-\alpha a_{w} \frac{d \beta}{d T}}{\alpha\left(2 \alpha a_{w}+\beta\right)} \\
& \frac{\partial a_{w}}{\partial T}=-\frac{\left[B C\left(\frac{(A+B T)}{X}\right)^{(C-1)}\right]}{\left[X\left(\left(\frac{(A+B T)}{X}\right)^{C}+1\right)^{2}\right]}
\end{aligned}
$$

The isosteric heats of sorption found at temperatures of 313.15 and $343.15 \mathrm{~K}$ for the jackfruit items are shown in Figure 2. The maximum values for the estimated $Q_{s t}$ were
56.61 and $51.49 \mathrm{~kJ} \cdot \mathrm{mol}^{-1}$ for the pulp, 54.14 and $50.96 \mathrm{~kJ} \cdot \mathrm{mol}^{-1}$ for the mesocarp, 49.46 and $46.53 \mathrm{~kJ} \cdot \mathrm{mol}^{-1}$ for the peel, 54.75 , $58.34 \mathrm{~kJ} \cdot \mathrm{mol}^{-1}$ for the peduncle, and 72.08 and $98.29 \mathrm{~kJ} \cdot \mathrm{mol}^{-1}$ for the seeds, at temperatures of 313.15 and $343.15 \mathrm{~K}$, respectively. The curves showed values that were very close for all the jackfruit items, in agreement with reports in the literature concerning the closeness of the two methods for estimating the isosteric heat of sorption (GARCÍA-PÉREZ et al., 2008; SIMAL et al., 2007; VILLA-VÉLEZ et al., 2012). The $Q_{s t}$ values decreased as the moisture content increased and were close to the water vaporization energy values at moisture contents over $0.050 \mathrm{~kg} \cdot \mathrm{kg}^{-1}$ (d.b) for the pulp, mesocarp, and peel items and were higher than $0.200 \mathrm{~kg} \cdot \mathrm{kg}^{-1}$ (d.b) for the peduncle and seed items. This can be explained quantitatively by considering that at low moisture contents and high temperatures, sorption occurs at the most active available sites, giving rise to great interaction energy. The value for $Q_{s t}$ was above zero, but tending to zero as the moisture content increased (MULET et al., 2002; RIZVI, 2005). In the graphs for the items peduncle and seed, intersections of the values for $Q_{s t}$ were observed at moisture contents of 0.130 and $0.040 \mathrm{~kg} \cdot \mathrm{kg}^{-1}$ (d.b) respectively. This phenomenon occurred at the initial values for the isosteric heat of sorption at the temperature of $343.15 \mathrm{~K}$, resulting from chemisorption on polar groups and the high rate of water evaporation caused by the reaction of lipids (seeds) and aromatic components (peduncle) of the jackfruit (CHINACHOTI, 1998).

The high heat of sorption values obtained for water at low moisture contents are an indication of the strong water-food component interactions in the jackfruit.

Figure 3 shows the evolution of differential entropy with the moisture content at temperatures of 313.15 and $343.15 \mathrm{~K}$. Differential entropy values represent the algebraic sum of the integral entropy at a particular hydration level plus the change in order or disorder after new water molecules are adsorbed by the system, at the same hydration level. Thus, the values for $\Delta S$ were 39.63 and $34.1 \mathrm{~kJ} \cdot \mathrm{mol}^{-1} \cdot \mathrm{K}^{-1}$ for the pulp, 37.98 and $33.64 \mathrm{~kJ} \cdot \mathrm{mol}^{-1} \cdot \mathrm{K}^{-1}$ for the mesocarp, 33.38 and $28.02 \mathrm{~kJ} \cdot \mathrm{mol}^{-1} \cdot \mathrm{K}^{-1}$ for the peel, 58.94 and $47.25 \mathrm{~kJ} \cdot \mathrm{mol}^{-1} \cdot \mathrm{K}^{-1}$ for the seed, and 75.60 and $71.36 \mathrm{~kJ} \cdot \mathrm{mol}^{-1} \cdot \mathrm{K}^{-1}$ for the peduncle, corresponding to the temperatures of 313.15 and $343.15 \mathrm{~K}$, respectively. These values corresponded to the maximum differential entropy, at which it was possible to observe changes in the ordering of the water molecules adsorbed onto the seeds as the moisture content increased. The differential entropies of the peduncle and seeds showed open-valued curves at the temperatures studied. Chinachoti (1998), who studied the degradation of grains and seeds during storage, argued that the sorption isotherm supposedly affects the seed properties because the water acts as a solvent, imparting mobility to the chemical constituents of the seeds by dissolution. This accounts for the increased chemical reaction rate, which is accelerated by temperature, relative humidity, and the initial seed moisture content. Free fatty acids are carboxylic acids released from triglycerides due to the action of lipase or oxidation. The risk of oxidation should be studied for the seeds as a function of the saturated and unsaturated fatty acids contents, which are especially sensitive. 

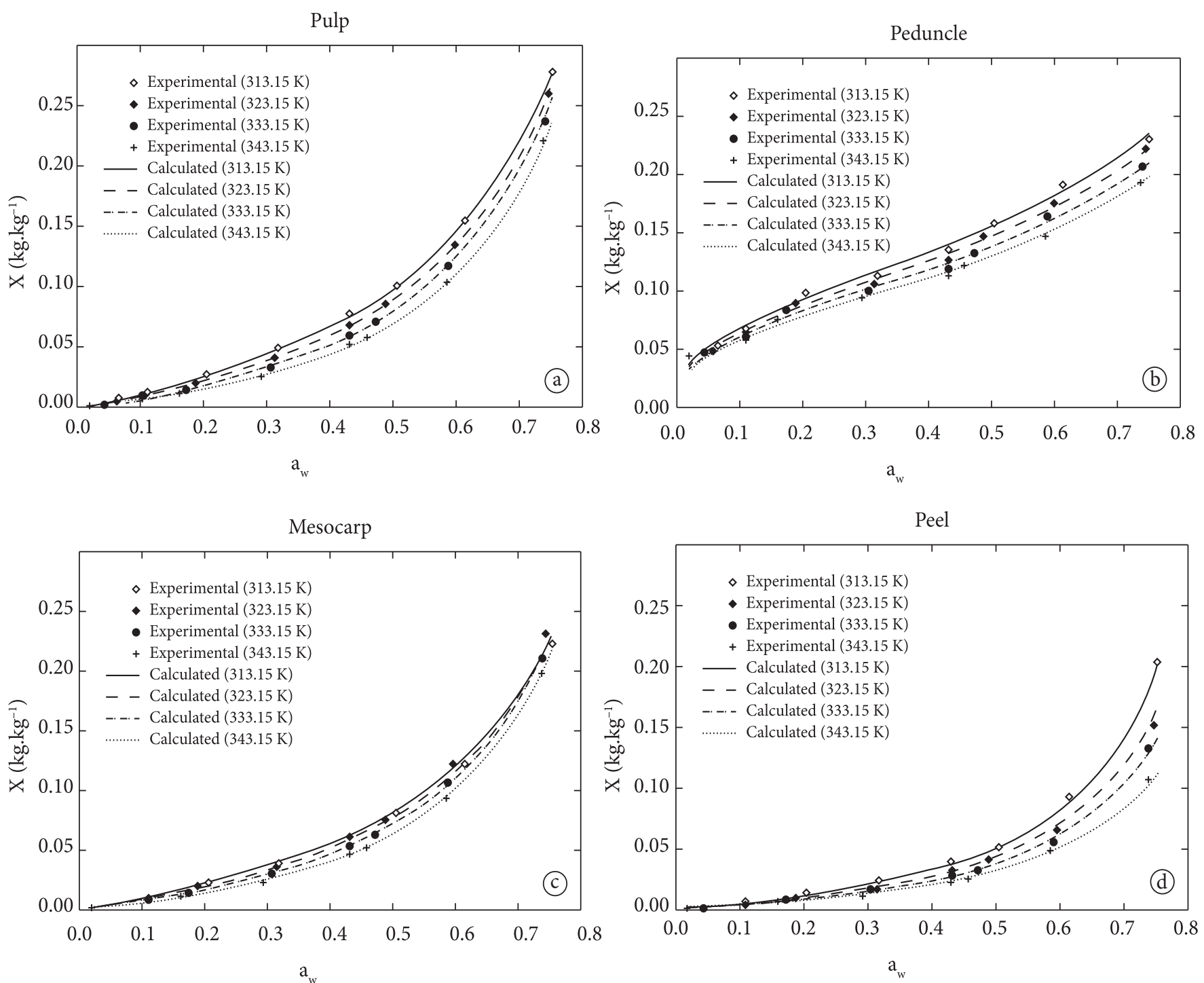

Seed

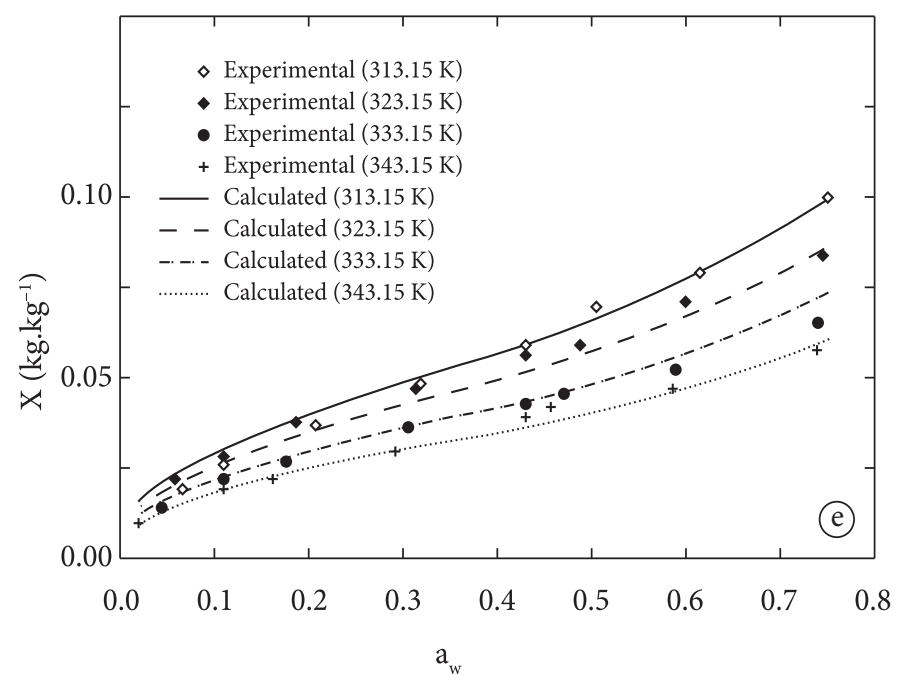

Figure 1. Experimental and calculated values for the desorption isotherms of (a) pulp, (b) peduncle, (c) mesocarp, (d) peel, and (e) seed prepared using the theoretical GAB model (items a, c, d) and the empirical Oswin model (items b, e). 

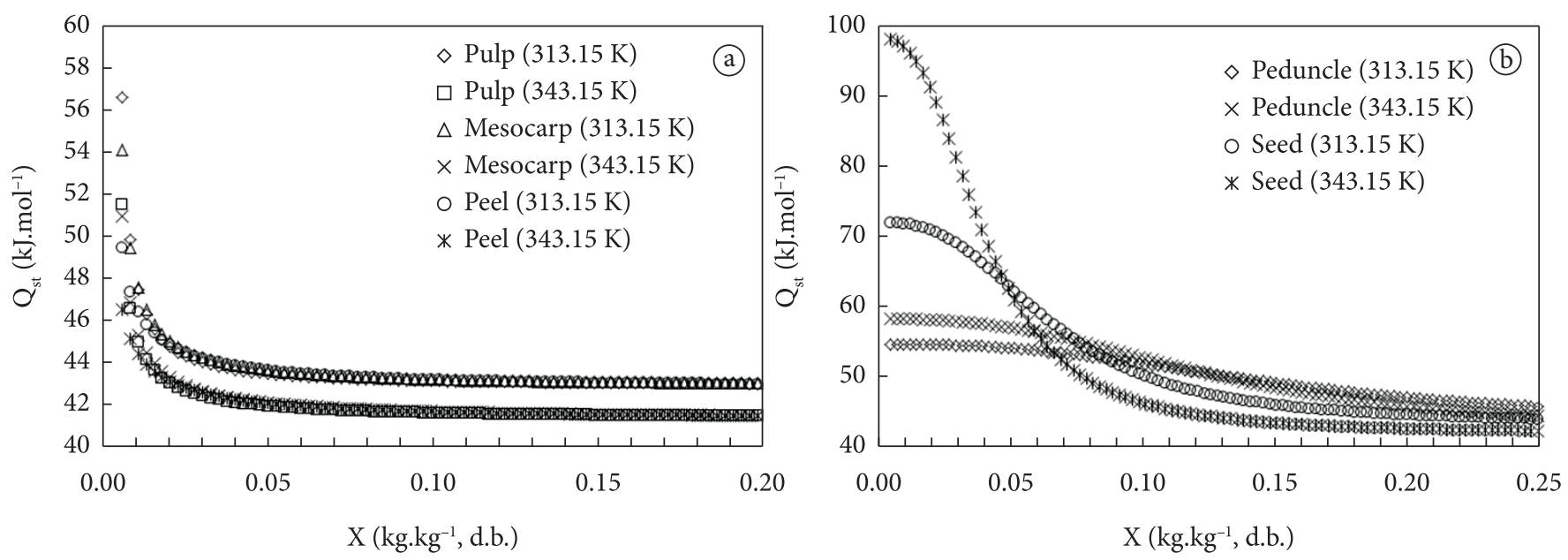

Figure 2. Isosteric heat of sorption for water of the different parts of jackfruit using the GAB (a) and Oswin (b) models at temperatures of 313.15 and $343.15 \mathrm{~K}$ as a function of the moisture content.
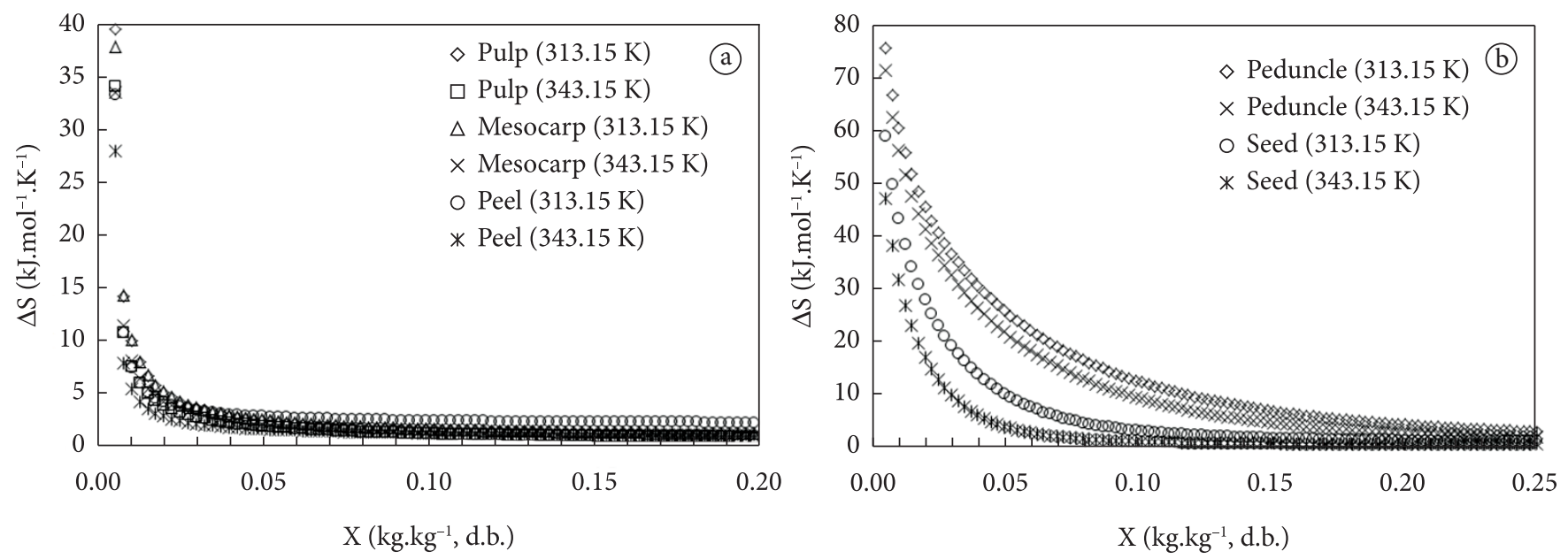

Figure 3. Differential entropy for water of the different parts of jackfruit using the GAB (a) and Oswin (b) models at temperatures of 40 and $70{ }^{\circ} \mathrm{C}$ as a function of the moisture content.
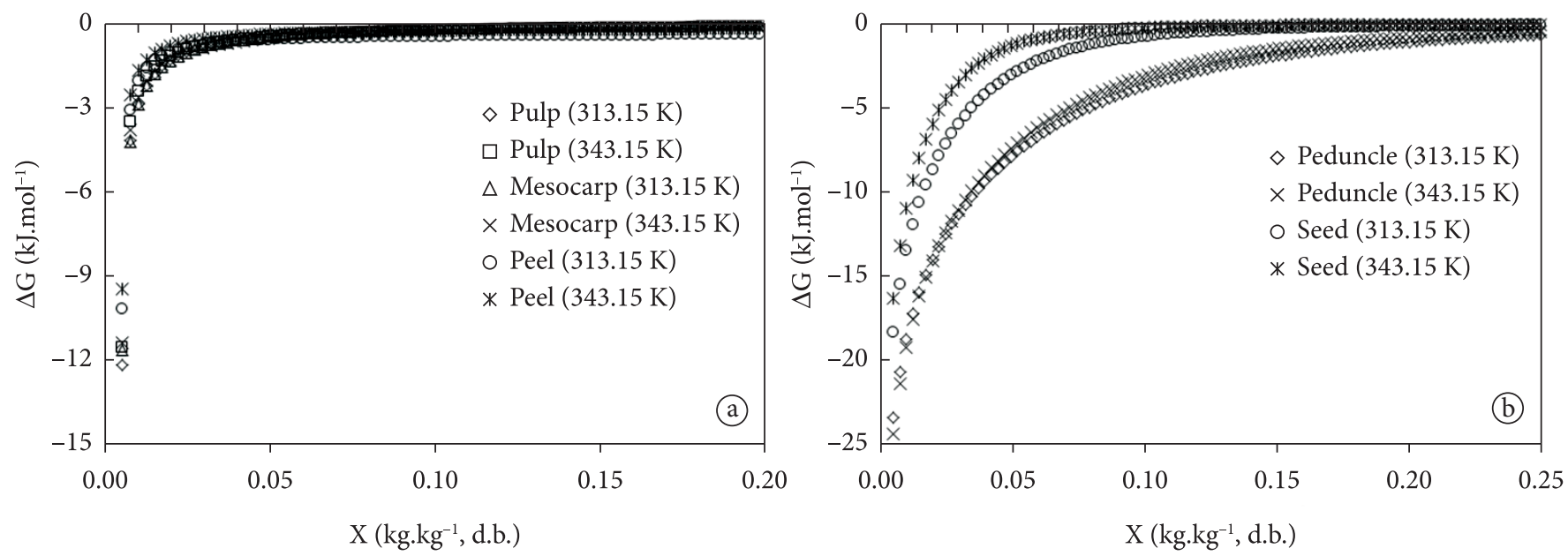

Figure 4. Gibbs' free energy for water of the different parts of jackfruit using the $\mathrm{GAB}$ (a) and Oswin (b) models at temperatures of 40 and $70{ }^{\circ} \mathrm{C}$ as a function of the moisture content. 
For the pulp, mesocarp, and peel, the water content at the minimum differential entropy was similar to the values obtained in the GAB monolayer because the maximum entropy change was caused by the water sorption at the most active sites. The value obtained for the monolayer represented saturation of the polar groups, corresponding to the water adsorbed at the most active sites.

Figure 4 shows the results for $\Delta G$ of all jackfruit items. The values for $\Delta G$ were -12.17 and $-11.54 \mathrm{~kJ} \cdot \mathrm{mol}^{-1}$ for the pulp, -11.63 and $-11.38 \mathrm{~kJ} \cdot \mathrm{mol}^{-1}$ for the mesocarp, -10.16 and $-9.43 \mathrm{~kJ} \cdot \mathrm{mol}^{-1}$ for the peel, -18.34 and $-16.28 \mathrm{~kJ} \cdot \mathrm{mol}^{-1}$ for the seed, and -23.42 and $-24.36 \mathrm{~kJ} \cdot \mathrm{mol}^{-1}$ for the peduncle at temperatures of 313.15 and $343.15 \mathrm{~K}$, respectively. These values were very close to each other and all below zero. The results for $\Delta G$ indicated that water sorption occurred in a spontaneous process. Moreover, the values showed that the reactions occurring in the microstructure of the product remained stable throughout the 313.15-343.15 K temperature range. In general terms, Figures 2 and 3 showed stronger intermolecular interactions or bonding (related to the enthalpy), which leads to a greater reduction in the freedom of configuration and hence to a greater order of the system (related to the entropy). This relationship might allow for the application of the enthalpyentropy compensation theory (KRUG; HUNTER; GRIEGER, 1976a, b) to the jackfruit items since the reaction rate should be similar for all reactions occurring at the temperatures evaluated.

\section{Conclusions}

Sorption isotherms were experimentally determined for the jackfruit items at $313.15,323.15,333.15$ and $343.15 \mathrm{~K}$, at a wide range of water activity and moisture content values. The $\mathrm{GAB}$ and Oswin models were used to adequately represent the desorption data at the temperatures studied. The GAB and Oswin models can be used to determine the analytical partial derivative of the water activity with respect to the temperature in the calculation of the Clausius-Clapeyron equation in order to determine the isosteric heat of sorption of water. The application of the aforementioned methodology allows one to calculate the value for $Q_{s t}$ directly, avoiding the linearization between $a_{w}$ versus $1 / T$ proposed and used by most authors. Moreover, the values for $\Delta S$ and $\Delta G$ were also calculated directly in the moisture content range of the isotherm desorption. The results obtained in the analyses of $Q_{s t}$ and $\Delta S$ suggest the need of further research on the influence of the fatty acid contents and aromatic compounds on the sorption isotherms for the seed and peduncle. Finally, the enthalpy-entropy compensation suggests a thermodynamic equilibrium, at which, from an analysis of $\Delta G$ in the same moisture content range, a spontaneous process was observed.

\section{Acknowledgements}

The authors are grateful to the National Council for Scientific and Technological Development (CNPq) and the Brazilian Institute of Geography and Statistics (IBGE) for the financial support.

\section{References}

AL-MuHTASEB, A. H.; McMinN, W. A. M.; MAGEE, T. R. A. Moisture sorption isotherm characteristics of food products: a review. Trans IChemE, v. 80, p. 118-128, 2002.

AMERICAN SOCIETY OF AGRICULTURAL ENGINEERS - ASAE. D271.2 DEC99: Psychrometric data. Madison: ASAE, 1998.

ANDERSON, R. B. Modifications of the Brunauer, Emmett and Teller equation. Journal of the American Chemical Society, v. 68, p. 686-691, 1946. http://dx.doi.org/10.1021/ja01208a049

ASQUIERI, E. R.; RABÊLO, A. M. D. S.; SILVA, A. G. M. Fermented jackfruit: study on its physicochemical and sensorial characteristics. Ciência e Tecnologia de Alimentos, v. 28, n. 4, p. 881-887, 2008. http://dx.doi.org/10.1590/S0101-20612008000400018

ASSOCIATION OF OFFICIAL ANALYTICAL CHEMISTS - AOAC. Offical Methods of Analysis of AOAC International. 16th ed. Gaithersburg: International AOAC, 1997. p. 1-5. Official Method 926.12. Moisture and volatile matter in oils and fats: vacuum oven method.

AVIARA, N. A.; AJIBOLA, O. O.; DAIRO, U. O. Thermodynamics of moisture sorption in sesame seed. Biosystems Engineering, v. 83, n. 4, p. 423-431, 2002. http://dx.doi.org/10.1006/bioe.2002.0124

BAHLOUL, N.; BOUDHRIOUA, N.; KECHAOU, N. Moisture desorption-adsorption isotherms and isosteric heats of sorption of Tunisian olive leaves (Olea europea L). Industrial Crops and Products, v. 28, p. 162-176, 2008. http://dx.doi.org/10.1016/j. indcrop.2008.02.003

BARBOSA-CÁNOVAS, G. V. et al. Water activity in foods: fundamentals and applications. Ames: Blackwell Publishing Profesional, 2007. 438 p. http://dx.doi.org/10.1002/9780470376454

BROVCHENKO, I.; OLEINIKOVA, A. Interfacial and confined water. Oxford: Elsevier, 2008. 317 p.

BRUNAUER, S. et al. On the theory of van der waals adsorption of gases. Journal of the American Chemical Society, v. 62, p. 1723-1732, 1940. http://dx.doi.org/10.1021/ja01864a025

BRUNAUER, S.; EMMETT, P. H.; TELLER, E. Adsorption of gases in multimolecular layers. Journal of the Chemistry Society, v. 60, p. 309-319, 1938. http://dx.doi.org/10.1021/ja01269a023

CAMPBELL, R.; EL-SAWA, S. F. The jackfruit, fairchild horticulture series. Miami: Fairchild Tropical Garden, 1998. p. 23-30.

CHANDRIKA, U. G.; JANSZ, E. R.; WARNASURIYA, N. D. Analysis od carotenoids in ripe jackfruit (Artocarpus heterophyllus) kernel and study of their bioconversion in rats. Journal of the Science of Food and Agriculture, v. 85, p. 186-190, 2005. http://dx.doi. org/10.1002/jsfa.1918

CHAYJAN, R. A. et al. Mathematical modelling of corn thermodynamic properties for desorption energy estimation. International Agrophysics, v. 24, p. 213-218, 2010. http://dx.doi.org/10.1016/ S0260-8774(02)00332-1

CHEN, C. Moisture sorption isotherms of pea seeds. Journal of Food Engineering, v. 58, p. 45-51, 2003.

CHEN, C.; MOREY, R. V. Comparations of four EMC/ERH equations. Transactions of the ASAE, v. 32, n. 3, p. 983-990, 1989.

CHEN, H. T.; HEN, R. A. Dehydration and storage stability of jackfruit leather. Journal of Food Science, v. 49, p. 1920-1930, 1975.

CHINACHOTI, P. Water migration and food storage stability. In TAUB, I. A.; SINGH, R. P. (Eds.). Food storage stability. New York: CRC Press, 1998. cap. 9, p. 1-23. 
DA-WEN, S. Comparison and selection of EMC/ERH isotherm equations for rice. Journal of Stored Products Research, v. 35, p. 249-264, 1999. http://dx.doi.org/10.1016/S0022-474X(99)00009-0

EIM, V. S. et al. Moisture sorption isotherms and thermodynamic properties of carrot. International Journal of Food Engineering, v. 7, n. 3, p. 1-18, 2011. http://dx.doi.org/10.2202/1556-3758.1804

GARCÍA-PÉREZ, J. V. et al. Water sorption isotherms for lemon peel at different temperatures and isosteric heats. LWT - Food Science and Technology, v. 41, p. 18-25, 2008.

GONELLI, A. L. D. et al. Water sorpotion isotherms and thermodynamic properties of pearl millet grain. International Journal of Food Science and Technology, v. 45, p. 828-838, 2010. http://dx.doi. org/10.1111/j.1365-2621.2010.02208.x

GUOLA, A. M. et al. Water sorption isotherms and glass transition temperature of spray dried tomato pulp. Journal of Food Engineering, v. 85, p. 73-83, 2008. http://dx.doi.org/10.1016/j. jfoodeng.2007.07.015

HAQ, N. Jackfruit: artocarpus heterophyllus. Southamton: Southamton Centre for Underutilised Crops, 2006.

HILL, T. L.; EMMETT, P. H.; JOYNER, L. G. Calculation of thermodynamic functions of absorbed molecules from adsorption isotherms measurements: nitrogen on graphon. Journal of Chemistry Physics, v. 73, p. 5102-5107, 1951.

IGLESIAS, H. A.; CHIRIFE, J. Prediction of the effect of temperature on water sorption isotherms of food materials. Journal of Food Technology, v. 11, p. 109-116, 1976. http://dx.doi. org/10.1111/j.1365-2621.1976.tb00707.x

JOWITT, R. et al. Physical properties methods of foods. 2nd ed. London: Applied Science Publishers, 1987. 564 p.

KAYA, S.; KAHYAOGLU, T. Thermodynamic properties and sorption equilibrium of pestil (grape skin). Journal of Food Engineering, v. 71, p. 200-207, 2005. http://dx.doi.org/10.1016/j. jfoodeng.2004.10.034

KAYA, S.; KAHYAOGLU, T. Moisture sorption and thermodynamic properties os safflower petals and tarragon. Journal of Food Engineering, v. 78, p. 413-421, 2007. http://dx.doi.org/10.1016/j. jfoodeng.2005.10.009

KHYRUNNISA, B. et al. Effect of replacement of cereal in rice rege diets by jackfruit seeds flour on the nutitive value of diets. Indian Journal of Nutrition and Dietetics, n. 26, p. 141-143, 1989.

KRUG, R. R.; HUNTER, W. G.; GRIEGER, R. A. Enthalpy-entropy compensation. 1 . Some fundamental statistical problems associated with the analysis of Von't Hoff and Arrhenius data. Journal of Physical Chemistry, v. 80, p. 2335-2341, 1976a. http://dx.doi. org/10.1021/j100562a006

KRUG, R. R.; HUNTER, W. G.; GRIEGER, R. A. Enthalpy-entropy compensation. 2. Separation of the chemical from the statistical effect. Journal of Physical Chemistry, v. 80, p. 2341-2351, 1976 b. http://dx.doi.org/10.1021/j100562a007
MENKOV, N. D. Moisture sorption isotherms of broan bean seeds. Nahrung, v. 44, p. 443-446, 2000. http://dx.doi.org/10.1002/15213803(20001201)44:6\%3C443::AID-FOOD443\%3E3.0.CO;2-1

MULET, A. et al. Equilibrium isotherms and isoteric heats of morel (Morchela esculenta). Journal of Food Engineering, v. 53, p. 75-81, 2002. http://dx.doi.org/10.1016/S0260-8774(01)00142-X

QUIÉVY, N. et al. Influence of homogenization and drying on the thermal stability of microfibrillated cellulose. Polymer Degradation and Stability, v. 95, p. 306-314, 2010. http://dx.doi.org/10.1016/j. polymdegradstab.2009.11.020

RIZVI, S. S. H. Thermodynamic Properties of Foods in Dehydration. In: RAO, M. A.; RIZVI, S. S. H.; DATTA, A. K. (Eds.) Engineering Properties of Foods. Boca Raton: Taylor \& Francis Group, 2005. cap. 7, p. 1-88.

SAMAPUNDO, S. et al. Sorption isotherms and isosteric heats of sorption of whole yellow dent corn. Journal of Food Engineering, v. 79, p. 168-175, 2007. http://dx.doi.org/10.1016/j. jfoodeng.2006.01.040

SHESKIN, D. Handbook of parametric and nonparametric statistical procedures. 3rd ed. Boca Raton: Taylor \& Francis Group, 2004. 972 p.

SIMAL, S. et al. Water desorption thermodynamic properties of pineapple. Journal of Food Engineering, v. 80, p. 1293-1301, 2007. http://dx.doi.org/10.1016/j.jfoodeng.2006.10.001

SIMBARASHE, S. et al. Sorption isotherms and isosteric heats of sorption of whole yellow dent corn. Journal of Food Engineering, v. 79, p. 168-175, 2007. http://dx.doi.org/10.1016/j. jfoodeng.2006.01.040

TELIS, V. R. N. et al. Water sorption thermodynamic properties applied to persimmon skin and pulp. Thermochimica Acta, v. 343, p. 49-56, 2000. http://dx.doi.org/10.1016/S0040-6031(99)00379-2

TIMMERMANN, E. O.; CHIRIFE, J.; IGLESIAS, H. A. Water sorption isotherms of foods and foodstuffs: BET or GAB parameters? Journal of Food Engineering, v. 48, p. 19-31, 2001. http://dx.doi. org/10.1016/S0260-8774(00)00139-4

TOGRUL, H.; ARSLAN, N. Moisture sorption isotherms and thermodynamic properties of walnut kernels. Journal of Stored Products Research, v. 43, p. 252-264, 2007. http://dx.doi. org/10.1016/j.jspr.2006.06.006

TSAMI, E.; KROKIDA, M. K.; DROUZAS, A. E. Effect of drying method on the sorption Characteristics of model fruits powders. Journal of Food Engineering, v. 38, p. 381-392, 1998. http://dx.doi. org/10.1016/S0260-8774(98)00130-7

VILLA-VÉLEZ, H. A. et al. Modelling thermodynamic properties of banana waste by analytical derivation of desorption isotherms. International Journal of Food Engineering, v. 8, n. 1, p. 1-21, 2012. http://dx.doi.org/10.1515/1556-3758.2191 